http://dx.doi.org/10.4314/jae.v16i2.13

\title{
Climate Change Vulnerability and the Use of Indigenous Technologies for Adaptation among Smallholder Farming Communities in sub Saharan Africa
}

\author{
Nicholas Ozor ${ }^{1}$, Kevin Urama and Wairimu Mwangi \\ African Technology Policy Studies Network \\ $3^{\text {rd }}$ Floor, The Chancery, Valley Road \\ P. O. Box $10081-00100$ \\ Nairobi, Kenya
}

\begin{abstract}
It has been established that climate variability and change has tremendous impacts on agricultural production and productivity especially in developing societies. Unfortunately, the extent of this change and the adaptation capacity in African agriculture has not been well determined to guide adaptation, policy and development efforts. This study aimed to obtain empirical evidence on whether and how smallholder farming communities are experiencing climate change variability and impacts and the indigenous technologies they have adopted to cushion the effects. The study was conducted in three sub Saharan African countries namely: Nigeria, Tanzania, and Sierra Leone. Primary data were collected through participant observations, questionnaire instruments, and focus group discussions while secondary data were obtained through in-depth literature reviews. Analysis of data was done using both descriptive and inferential statistics. Major findings revealed that the farming communities in the case study countries were indeed experiencing climate change variability and impacts. The most common indigenous technologies that have been continually applied by these farming communities include; multiple cropping to diversify production; early or late planting; mulching to retain soil moisture, texture and fertility; terrace building to prevent soil erosion; use of fertilizers; and prayers for God's intervention among others. Although most indigenous technologies have been considered effective in coping with climate variability in the past, it remains unclear on how effective they will be in the light of further warming. However, it was recommended that the most effective and sustainable indigenous technologies used by the farming communities could be incubated with a view to upscale and out scale them in other areas so as to enhance adaptation to climate change and variability.
\end{abstract}


Key Words: Climate Change, Vulnerability, Indigenous technology, Adaptation, Agriculture, Smallholder farmers, sub Saharan Africa

\section{Introduction}

Climate change is considered to be one of the most unprecedented threats of our time. Although climate change is not a new phenomenon, its recent usage, especially in the context of development, refers to changes in the prevailing climate, particularly since the $20^{\text {th }}$ century and the perceived impacts on the economy and livelihoods (Adebayo, Dauda, Rikko, George, et al., 2011). Climate patterns play a fundamental role in shaping natural ecosystems, human economies and cultures that depend on them. Therefore, a change in climate has implications on the livelihoods of humans, animals, plants, and the ecosystems.

According to the Fourth Assessment Report of the United Nation's Intergovernmental Panel on Climate Change (IPCC, 2007), over the last century, atmospheric concentrations of carbon dioxide increased from a pre-industrial value of 278 parts per million (ppm) to $379 \mathrm{ppm}$ in 2005 and as a result the average global temperature rose by $0.74{ }^{\circ} \mathrm{C}$. The IPCC report gives detailed projections for the $21^{\text {st }}$ century and these show that global warming will continue and even accelerate. The best estimates predict that the earth could warm by $3^{\circ} \mathrm{C}$ by 2100 . This warming is critical because even with a temperature increase of between 1$2.5^{\circ} \mathrm{C}$ serious effects are predicted which include reduced crop yields in tropical areas leading to increased risk of hunger, spread of climate sensitive diseases such as malaria, and an increased risk of extinction of around 20-30 per cent of all plant and animal species. The major concern is that if global warming continues unabated, it may create further risks that will erode all the development achievements made in vulnerable economies such as Africa's.

There is therefore a strong consensus among experts that climatic variability will have drastic consequences on agricultural production and productivity (Watson, 2010). IPCC considers Africa to be the most vulnerable to the impacts of climate change and variability. This vulnerability arises from and is heightened by factors such as the overdependence on rain-fed agricultural production by most small holder farmers and overall economies in most African countries. Agriculture is the economic mainstay for most African economies. It provides employment and livelihood sustenance for the majority of the population. Apart from oil exporting countries, most of sub-Saharan African countries rely on agriculture which contributes about $20-30 \%$ of its gross domestic product (GDP) and $55 \%$ of the total value of African exports.

There is also the presence of multi-stressors which have a synergistic effect when they interact with climate change and variability impacts and tend to lower the adaptive capacity of smallholder farmers to the prevailing risks. Even without climate change, Africa's agricultural development has been severely constrained by several multi-stressors that include: poverty, poor governance, underdeveloped markets, lack of sufficient infrastructure, low technological capacity and adoption 
etc. Climate change coupled with these multi-stressors will exert further pressure on agriculture with a direct bearing on the economy, food security, and the attainment of development goals such as the United Nations Millennium Development Goals (MDGs) (Ozor, Madukwe, Onokala, and Enete et al., 2010).

Maintaining a business as usual (BAU) scenario will therefore compromise agricultural production including access to food in many African countries. The IPCC projects that by 2020 , yields from rain-fed agriculture could be reduced by up to $50 \%$ in some countries (IPCC, 2007). FAO (2007) reports indicate that up to $11 \%$ of arable land could be highly affected by climatic change in the developing world which would adversely result into food insecurity and exacerbate malnutrition. At the global scale, a decrease of up to $30 \%$ in the world food production due to effects of climate change on agriculture is generally predicted (IPCC 2007).

As a result of this vulnerability, climate change and agriculture have become central to Africa's development goals. Unfortunately, predicting the impact of climate change on complex biophysical and socio-economic systems of smallholder agriculture is very difficult. This difficulty has been attributed to the lack of standardized definitions of these kinds of smallholder farming systems; the intrinsic characteristics of these systems, particularly their complexity, their location specificity, and their integration of agricultural and nonagricultural livelihood strategies and; the vulnerability of smallholder farming systems to a range of climate related stressors.

Nevertheless, many African smallholder farming communities have thrived for decades and centuries even in the face of changing climate (Ozor, Madukwe, Onokala, and Enete et al., 2010). The continued survival and existence of such communities in the face of emerging climate challenges have been attributed to their use and application of several indigenous knowledge techniques most of which have been modified continually and passed on from one generation to another. In the recent times, technological innovations are emerging as key intervention tools for climate change adaptation and mitigation and for the attainment of other development goals. However, there is very little appreciation for the indigenous knowledge and technologies that have been applied to address these challenges in the past. Traditionally, African farmers have used indigenous knowledge to understand weather and climate patterns in order to guide their decisions in crop and livestock management.

The pertinent questions to ask therefore are: what evidence of climate vulnerability and change are prevalent in the study area? What are the factors that influence vulnerability to climate change among smallholder farmers? And what are the indigenous technologies used by these farmers in adapting to the climate change? These questions guided the discussions in this paper. 


\section{Purpose and Objectives}

The overall purpose of the research study was to verify climate change vulnerability and the use of indigenous technologies for adaptation among smallholder farming communities in sub Saharan Africa. Specifically, the study was meant to:

1. assess evidence of climate change impacts among smallholder farming communities in selected farming communities in sub Saharan Africa;

2. determine the factors that influence vulnerability to climate change among the smallholder farmers; and

3. identify the indigenous technologies that communities have adopted in coping with climate variability and change.

\section{Methodology}

This paper is a synthesis of the research studies conducted in the three country cases of Nigeria (Southwest and Southeast), Sierra Leone and Tanzania on climate change vulnerability and the use of indigenous technologies for adaptation among the smallholder farming communities.

\section{Population and Sample Size}

The population and sample of the study comprised of smallholder farmers from the three countries as described below according to country cases.

\section{Nigeria}

\section{Southwest Nigeria}

Southwest Nigeria is made up of Lagos, Ogun, Oyo, Osun, Ondo and Ekiti States. The three main agro-ecological zones in the area are the swamp on the Atlantic coast, tropical rainforest in the middle and guinea savanna in the north. A random sample of three rural communities was selected from each of these agroecological zones from the village listing available with the Agricultural Development Programmes (ADPs responsible for field level agricultural extension services) covering the Ogun State for the swamp locations; Ondo State for the rainforest locations and Oyo State for the savanna locations. In each of the nine locations selected for the study, a systematic sample of 41 farmers (taking into consideration the variety of agricultural activities in each community) was selected. A total of 369 farmers were selected for interview by trained enumerators. These farmers cover the broad range of farming systems practices in southwest Nigeria and their perspectives on indigenous and emerging technologies and how these have or can help to cope with climate change. However, only 362 questionnaire instruments were used for further analysis comprising of 119 from the swamp 
agro-ecological zone, 120 from the rainforest and 123 from the savanna zone giving a response rate of $98.1 \%$. In addition, a sample of 150 extension officers was systematically selected from the staff list of the Agricultural Development Programmes (ADPs) in the three agro-ecological zones of Southwest Nigeria. Another sample of 30 researchers working on areas bordering climate change and agriculture was also purposively selected for this study. It was anticipated that these researchers and extension officers will provide further insights and perspectives into the farming systems in Southwest Nigeria and their influence on climate change.

\section{Southeast Nigeria}

This study was done in the southeast geo-political zone, comprising Abia, Anambra, Ebonyi, Enugu and Imo. The zone is particularly vulnerable to ecological problems, especially soil erosion in all forms. Two states, Enugu and Imo states were randomly selected for the study. In each selected state, two agricultural zones were then randomly selected. These were Owerri and Okigwe in Imo State and Enugu and Nsukka in Enugu State. In each agricultural zone and with the assistance of the extension agency- ADP, farming communities were compiled, from which two communities were randomly selected making a total of eight communities for the study. In each selected community, a list of farm households was compiled, also with the assistance of extension agents, from which 50 farmers were randomly selected, bringing the total sampled respondents to 400 for the study.

\section{Sierra Leone}

The sample frame of the research is the entire smallholder farming population of Sierra Leone. Given that $75 \%$ of the population is estimated to be smallholder farmers, it therefore means that a total of 3.675 million farm families form the population of the study in Sierra Leone. A sample size of 500 farm families was eventually selected using a multi-stage random sampling technique. In the first stage, the four agro-climatic regions in Sierra Leone were identified. The agroclimatic regions were then divided into districts, which were further subdivided into chiefdoms and localities. In all five districts, twelve chiefdoms and thirty-four localities were randomly selected. One district was selected from each of the four agro-climatic regions with the exception of the transitional agro-climatic zone (from where two districts were selected based on the administrative size of the zone). A total of 125 questionnaire instruments were equally administered to farmers using simple random sampling technique in each of the agro-climatic regions making a total of 500 respondents. In addition, 10 Focus Group Discussions (FGDs) were conducted with identified farmers' groups in each of the regions.

\section{Tanzania}

The Tanzanian case study was carried out in two different districts of Mpwapwa and Lushoto. The two districts possess distinctive characteristics as the Mpwapwa district in Dodoma Region is semi-arid while Lushoto district found in Tanga region 
has a humid environment. A total of 400 heads of households, 200 from each district were interviewed. In each of the two districts where the study was carried out, four villages were selected whereby a total of fifty respondents were interviewed using the questionnaire in each village. In-depth interviews with heads of households using a structured questionnaire with both open-ended and close ended questions were conducted.

\section{Data Collection}

The research was based on field surveys and desk studies which were carried out in the year 2010 in the selected sub Saharan African countries of Nigeria, Sierra Leone and Tanzania. These countries were selected to reflect a sub-Saharan African representation. The field surveys were mainly conducted through interviews by administering questionnaire instruments to smallholder farming households. The interviews conducted were complemented by focus group discussions to capture other decision makers such as government administrators including chiefs, extension officers, community and religious leaders among others. The secondary data was obtained through in-depth literature review of published and unpublished articles from journals, research papers and authentic official reports.

The techniques that were used for data collection entailed structured questionnaire instruments, semi-structured interviews, key informant interviews, as well as focus group discussions. The questionnaire instruments sought to: characterize the respondents according to socio-economic status, ascertain their awareness of climate change variability, assess the evidences of climate change impacts, and the factors that influence smallholder farmers' vulnerability to climate change. It also sought to identify the indigenous technologies that are in use by the smallholder farmers to adapt to the impacts of climate change impacts.

\section{Data analysis}

Data from the study were analyzed using both descriptive and inferential statistics. Objectives one and three were mainly analyzed using descriptive statistics including narratives, frequency, percentage and mean scores, while objective two was analyzed using correlation and regression analysis. Most of the qualitative data collected were analyzed using content analysis.

\section{Results and Discussions}

\section{Climate change variability and impact on agriculture}

\section{Climate Variability}

Results from most of the smallholder farming communities in the case study countries showed that there were climate change variability and impacts particularly on agriculture. Although the level of these climate variability varies considerably based on various factors, the most notable observations in Nigeria, 
Sierra Leone and Tanzania were: early rains that were not sustained, erratic rainfall, delay in the onset of rain, long period of dry season, thunderstorms, heavy winds, and intense heat waves (Adebayo, Dauda, Rikko, George, et al., 2011; Enete, Madu, Mojekwu, Onyekuru et al., 2011; Morlai, Mansaray and Vandy, 2011; and Shemdoe, 2011). Adebayo, Dauda, Rikko, George, et al. (2011) specifically reported significant decline of rainfall frequency i.e. the number of rainy days in September and October in the southwest region of Nigeria which respectively coincides with the end of the rainy season in the northern and southern parts of the country, leading to a decrease in the annual rain days over the entire country. Floods have become a common feature of Nigerian climate; the country is experiencing extreme rainfall conditions, one of drought and the other of floods. Other studies have also shown that there has been precipitation decrease in the humid regions of West Africa, including parts of southern Nigeria since the beginning of the century to between $10-25 \%$ per decade. In Nigeria, this is evidenced by the late arrival of rains, drying up of streams and small rivers that usually flow all year round, the seasonal shifting of the "Mango rains" and that of the fruiting period in the southern Oyo State and the gradual disappearance of flood-recession cropping in riverine areas of Ondo State (Adebayo, Dauda, Rikko, George, et al., 2011). In Sierra Leone, the farmers not only experienced climate change and variability but about $72 \%$ mentioned that extreme weather changes (particularly rainfall, heat and cold) were recent phenomena that have been observed in the past 2-3 years (Morlai, Mansaray and Vandy, 2011). 
TABLE 1

Perceived views of smallholder farmers on climate change and variability in Sierra Leone

\begin{tabular}{|c|c|c|c|c|c|}
\hline \multirow{2}{*}{ Observations } & \multicolumn{4}{|c|}{ Agro-climatic regions } & \multirow[b]{2}{*}{ Total } \\
\hline & $\begin{array}{l}\text { Coastal } \\
\text { plains }\end{array}$ & Rainforests & $\begin{array}{l}\text { Savanna } \\
\text { Woodlands }\end{array}$ & $\begin{array}{l}\text { Transitional } \\
\text { Rainforests/ } \\
\text { Savanna } \\
\text { Woodlands }\end{array}$ & \\
\hline $\begin{array}{l}\text { Long rainfall } \\
\text { duration }\end{array}$ & $95(76.6 \%)$ & $105(84.0 \%)$ & $99(82.5 \%)$ & $67(53.6 \%)$ & $366(74.1 \%)$ \\
\hline $\begin{array}{l}\text { Short and } \\
\text { heavy rainfall }\end{array}$ & $51(41.1 \%)$ & $15(12.0 \%)$ & $73(60.8 \%)$ & $70(56.5 \%)$ & $209(42.4 \%)$ \\
\hline $\begin{array}{l}\text { Long dry } \\
\text { season }\end{array}$ & $94(75.8 \%)$ & $44(35.2 \%)$ & $104(86.7 \%)$ & $60(48.0 \%)$ & $302(61.1 \%)$ \\
\hline $\begin{array}{l}\text { Late start of } \\
\text { farming }\end{array}$ & $50(40.3 \%)$ & $13(10.4 \%)$ & $10(8.3 \%)$ & $70(56.0 \%)$ & $143(28.9 \%)$ \\
\hline $\begin{array}{l}\text { Early start of } \\
\text { farming }\end{array}$ & $30(24.2 \%)$ & $77(61.6 \%)$ & $30(25.0 \%)$ & $89(71.2 \%)$ & $226(45.7 \%)$ \\
\hline $\begin{array}{l}\text { Higher } \\
\text { temperature }\end{array}$ & $92(74.2 \%)$ & $46(36.8 \%)$ & $86(71.7 \%)$ & $45(36.0 \%)$ & $269(54.5 \%)$ \\
\hline Others & $122(98.4 \%)$ & $6(4.8 \%)$ & $109(90.8 \%)$ & $97(77.6 \%)$ & $334(67.6 \%)$ \\
\hline
\end{tabular}

Source: Morlai, Mansaray and Vandy, 2011

From the data in Table 1, it could be observed that there were mixed patterns of change in climatic variables particularly between the different agro-climatic regions in Sierra Leone. Generally, the highest observations by the farmers were long rainfall duration (74\% of responses), long dry season (61\% of responses) and high temperatures ( $55 \%$ of responses).

\section{Climate Change Impacts}

The most common climate change impacts observed in the countries case studies were; the proliferation of pests, diseases and weeds; signals of land degradation such as declining soil fertility, reduced yields and drying up of streams and rivers (Adebayo, Dauda, Rikko, George, et al., 2011; Enete, Madu, Mojekwu, Onyekuru et al., 2011; Morlai, Mansaray and Vandy, 2011; and Shemdoe, 2011). Reduction in storage quality of crops, loss of crop and animal ecosystem, and reduction in farm size were also specifically observed in Southeast Nigeria (Enete, Madu, Mojekwu, Onyekuru et al., 2011). 
TABLE 2

Perceived views of smallholder farmers on climate change and variability in Southwest Nigeria

\begin{tabular}{|c|c|c|c|c|}
\hline & \multicolumn{4}{|c|}{ Agro-ecological zones } \\
\hline $\begin{array}{l}\text { Climate Change } \\
\text { effects } \\
\text { None }\end{array}$ & $\begin{array}{l}\text { Swamp } \\
(n=119)\end{array}$ & $\begin{array}{c}\text { Rainforest } \\
(\mathbf{n}=120) \\
0.00 \%\end{array}$ & $\begin{array}{c}\text { Savanna } \\
(n=123) \\
4.07 \%\end{array}$ & $\begin{array}{c}\begin{array}{c}\text { Overall } \\
(n=362) \\
1.38 \%\end{array} \\
\end{array}$ \\
\hline Reduction in crop yield & $\begin{array}{l}0.00 \% \\
47.06 \%\end{array}$ & $39.17 \%$ & $93.50 \%$ & $60.22 \%$ \\
\hline Low productivity & $0.00 \%$ & $46.67 \%$ & $0.00 \%$ & $15.47 \%$ \\
\hline $\begin{array}{l}\text { Storms damage boats, nets and capsized } \\
\text { boats }\end{array}$ & $42.86 \%$ & $0.00 \%$ & $0.00 \%$ & $14.09 \%$ \\
\hline Windstorm damages buildings & $5.04 \%$ & $0.00 \%$ & $0.00 \%$ & $1.66 \%$ \\
\hline Outbreak of diseases & $0.00 \%$ & $3.33 \%$ & $0.00 \%$ & $1.10 \%$ \\
\hline Windstorms destroying processing sheds & $2.52 \%$ & $0.00 \%$ & $0.00 \%$ & $0.83 \%$ \\
\hline $\begin{array}{l}\text { Others: (Evapo-transpiration, High } \\
\text { livestock mortality, High temperature led } \\
\text { to migration of fishes and heat stress on } \\
\text { plants) }\end{array}$ & $2.52 \%$ & $1.66 \%$ & $2.43 \%$ & $2.24 \%$ \\
\hline No response & $0.00 \%$ & $9.17 \%$ & $0.00 \%$ & $3.04 \%$ \\
\hline
\end{tabular}

Source: Adebayo, Dauda, Rikko, George, et al., 2011

The findings in Table 2 showed that farmers were mainly concerned on how climate change is contributing to reduction in crop yield (60\%) and low productivity $(15 \%)$ of their agricultural produce. This finding is in line with the IPCC (2007) and FAO (2007) reports that climate change could reduce agricultural yields by up to $50 \%$. This therefore calls for concerted integrated efforts to adapt and mitigate the environmental challenge. 
TABLE 3

The direction of change of climate change phenomena and extent of contribution of phenomena to climate change

\begin{tabular}{|c|c|c|c|c|}
\hline $\begin{array}{l}\text { Phenomena that has } \\
\text { been worsening in } \\
\text { the last } 10 \text { years }\end{array}$ & $\begin{array}{l}\text { Increasing } \\
\text { (IC) }\end{array}$ & $\begin{array}{l}\text { Decreasing } \\
\text { (DC) }\end{array}$ & No change & $\begin{array}{l}\text { Mean extent of } \\
\text { climate change } \\
\text { contribution }\end{array}$ \\
\hline \multicolumn{5}{|l|}{$\begin{array}{l}\text { Uncertainties in the } \\
\text { onset of farming } \\
\text { season }\end{array}$} \\
\hline $\begin{array}{l}\text { Unusual early rains } \\
\text { that are not sustained }\end{array}$ & 83 & 13 & 4 & 3.5 \\
\hline $\begin{array}{l}\text { Delay in the onset of } \\
\text { rain }\end{array}$ & 89 & 7 & 3 & 3.6 \\
\hline $\begin{array}{l}\text { Long period of dry } \\
\text { season }\end{array}$ & 80 & 16 & 4 & 3.4 \\
\hline $\begin{array}{l}\text { Rainfall } \\
\text { Climate change } \\
\text { Impacts }\end{array}$ & 15 & 82 & 3 & 3.0 \\
\hline $\begin{array}{l}\text { Loss of forest } \\
\text { resources }\end{array}$ & 35 & 25 & 40 & 3.3 \\
\hline Soil erosion & 38 & 47 & 15 & 3.1 \\
\hline $\begin{array}{l}\text { Decrease in soil } \\
\text { moisture }\end{array}$ & 71 & 20 & 9 & 3.3 \\
\hline Presence of Pests & 59 & 32 & 9 & 3.5 \\
\hline Presence of diseases & 58 & 27 & 15 & 3.5 \\
\hline Presence of weeds & 38 & 26 & 36 & 3.1 \\
\hline
\end{tabular}

Source: Enete, Madu, Mojekwu, Onyekuru et al., 2011. Mean cut off mark= 3.0

Table 3 shows increasing incidences of unusual early rains that were not sustained, erratic rainfall, delay in the onset of rain, long period of dry season, less rainfall, and higher temperature. All the mean scores of the phenomena that have been worsening during the past 10 years were seen to be more than the cut off mark. This indicates that the farmers attributed these phenomena to the changes in climate. Under the impacts, the respondents observed some increases in the presence of pests, diseases and weeds.

\section{Factors Contributing to Climate Change and Variability}

At the farmer level, knowledge on agricultural impacts and contribution to climate change is fairly good in terms of linking their farming practices to climate change effects. In Southwest Nigeria, $65 \%$ of the farmers felt that farming activities contribute significantly to climate change and they associated it with bush burning, use of chemicals and deforestation (Table 4). In Southeast Nigeria, about $52 \%$ of the respondents believed that farming contributes to climate change. A considerable number also attribute the major effects of climate change to industrial 
activities and urbanization such as from industrial chemicals, construction activities, emission of gases, flaring of gases, quarrying activities, and smokes from cars.

TABLE 4

Farmers' perspectives on the causes of climate change in the three agroecological zones of southwest Nigeria and their examples

\begin{tabular}{|c|c|c|c|c|c|}
\hline \multicolumn{6}{|c|}{ Agro-ecological Zones } \\
\hline Causes & $\begin{array}{l}\text { Swamp } \\
(n=119)\end{array}$ & $\begin{array}{l}\text { Rainforest } \\
(n=120)\end{array}$ & $\begin{array}{l}\text { Savanna } \\
(n=123)\end{array}$ & $\begin{array}{l}\text { Overall } \\
(n=362)\end{array}$ & Examples \\
\hline $\begin{array}{l}\text { Industrial } \\
\text { activities }\end{array}$ & 9.24 & 30.83 & 3.25 & 14.36 & $\begin{array}{l}\text { Construction, } \\
\text { Emissions of gases, } \\
\text { Flaring of gases, } \\
\text { Petroleum, Quarry, } \\
\text { Smoke from diesel or } \\
\text { petrol engines, } \\
\text { Smoking, Use of } \\
\text { Chemicals, Water } \\
\text { Pollution }\end{array}$ \\
\hline $\begin{array}{l}\text { Farming } \\
\text { Activities }\end{array}$ & 84.03 & 55.83 & 57.72 & 65.75 & $\begin{array}{l}\text { Bush burning, } \\
\text { Chemicals } \\
\text { (herbicides), } \\
\text { Deforestation }\end{array}$ \\
\hline Transportation & 8.40 & 17.50 & 9.76 & 11.88 & $\begin{array}{l}\text { Emission of } \\
\text { dangerous gases, } \\
\text { Smoke from diesel } \\
\text { or petrol engine }\end{array}$ \\
\hline $\begin{array}{l}\text { Agro- } \\
\text { processing }\end{array}$ & 3.36 & 19.17 & 6.50 & 9.67 & $\begin{array}{l}\text { Agro Allied waste, } \\
\text { deforestation, } \\
\text { Pesticides, Release } \\
\text { of smokes, Smoking }\end{array}$ \\
\hline Urbanization & 4.20 & 55.00 & 17.07 & 25.41 & $\begin{array}{l}\text { Civilization, } \\
\text { Deforestation, } \\
\text { Emission of gases, } \\
\text { Improper disposal of } \\
\text { waste discharge }\end{array}$ \\
\hline
\end{tabular}

Source: Adebayo, Dauda, Rikko, George, et al., 2011

It is however noteworthy that most of these activities that are carried out by farmers such as burning of wood fuel is a requirement to meet the growing energy demands of communities as other alternative sources are expensive and out of reach for most smallholder farming communities. Also due to the decrease in soil fertility, farmers have resulted in excessive use of fertilizers to regain the soil fertility and improve on the declining crop productivity. 


\section{Factors Influencing Vulnerability to Climate Change Impacts among Smallholder Farmers}

\section{Education/Awareness levels}

Majority of the farmers in the case studies were generally aware of climate change and stated that they experienced climate change impacts and have adopted measures to cope and adapt to the changes (Adebayo, Dauda, Rikko, George, et al., 2011; Enete, Madu, Mojekwu, Onyekuru et al., 2011; Morlai, Mansaray and Vandy 2011). The Southwest Nigeria case study showed that levels of education were significant in explaining farmers' observation of changes in climate parameters such as temperature, rainfall and wind variability (Adebayo, Dauda, Rikko, George, et al., 2011). Those with higher educational level had better knowledge and understanding of the concept. The Southeast Nigeria case study also showed that education was significant in demonstrating the level of investment in indigenous climate change adaptation practices (Enete, Madu, Mojekwu, Onyekuru et al., 2011). In the case of whether climate change impacts agriculture, the communities for Southwest and Southeast Nigeria, had a positive response at the rate of $97 \%$ and $96 \%$ respectively. This knowledge is important for the adoption of technologies and behavioral change to adapt to climate change.

Communities' awareness levels have been considered to be important in adapting to climate change. For example, Araya and Adjaye (2001) and Anim (1999) stated that farmers awareness and perceptions of the soil erosion problem as a result of changes in climate, positively and significantly affected their decisions to adopt soil conservation measures. Improved education and dissemination of knowledge are important policy measures for stimulating awareness and local participation in various development and national resource management initiatives (Anley, Bogale and Haile-Gabriel, 2007). Maddison (2006) argued that educated and more experienced farmers have more knowledge and information about climate change and agronomic practices that they can adopt to respond to the situation.

\section{Age of farmers}

Older farmers are generally perceived to be risk averse particularly in the uptake of new technologies or in changing from old farming systems to new ones. However, most of the results from the case study countries showed that older farmers were more responsive to climate change impacts. For instance in the case of Southwest Nigeria, the results showed that the older farmers have observed lower volumes of rainfall which is supported by several literature findings but the younger ones observed an increase in rainfall (Adebayo, Dauda, Rikko, George, et al., 2011). Enete, Madu, Mojekwu, Onyekuru et al., (2011) argued that it is likely that age may endow the farmers with requisite experience that empower them to make better assessments of the prevailing risks.

Other findings from Tanzania showed that agriculture is being practiced by farmers in their productive ages (Shemdoe, 2011). According to (Enete, Madu, Mojekwu, Onyekuru et al., 2011) the participation of more young people in agricultural 
practices could be attributed to the high unemployment rates that have influenced the young people to explore opportunities in agriculture. By and large, experience in farming practices is important in understanding the dynamics of the agricultural system and influences from climate change and the requisite interventions.

Differences in agro-ecological zones were quite significant in demonstrating the varying climate variability and impacts. In Southwest Nigeria, it was observed that although farmer's socio-economic characteristics such as marital status, gender, level of education, age, household size and income, explained changes observed in the general climatic phenomena they were not as significant as the variations in agro-ecological zones. For instance a large proportion of farmers in the rain forest zone observed lower winds while almost the same proportion of farmers in savanna zone observed higher winds in Southwest Nigeria (Adebayo, Dauda, Rikko, George, et al., 2011). Likewise for rainfall, more than $93 \%$ of the respondents in the rainforest and swamp zones perceived that temperatures were higher while only about $56 \%$ supported this in the savannah zone.

Enete, Madu, Mojekwu, Onyekuru et al., (2011) reported that the impacts observed by farming communities were significantly higher for Imo State than for Enugu State. This was attributed to the fact that Imo region is closer to the sea than Enugu State and climate change induced sea level rises and associated inland effects are more pronounced in Imo State than in Enugu State. However, it is worth noting that Enugu is a drier region that has been experiencing drier and more variable weather patterns over time. Two districts; Lushoto and Mpwapwa areas of Tanzania also showed variations in proliferation of pests and diseases with $42 \%$ and $80 \%$ of the reported cases respectively. Lushoto district is a humid agro-ecological zone while Mpwapwa district is a semi-arid zone.

\section{Income levels}

Income level is a key factor in influencing adoption of technologies as demonstrated by the findings in the Southwest Nigeria scenario. In this area, farmers in the rainforest and swamp areas adopted technologies with ease than their counterparts in the savanna region who had less income from their primary occupation (Adebayo, Dauda, Rikko, George, et al., 2011). Generally, although crop farming is a dominant activity, it is usually supplemented by other income earning activities. In the case of Southeast Nigeria, civil servants were highly engaged in farming activities to supplement their eroding purchasing power as a result of inflation in the economy (Enete, Madu, Mojekwu, Onyekuru et al., 2011). 


\section{Coping Strategies and Use of Indigenous Technologies}

The several case studies showed that farmers used various coping and adaptation strategies most of which were derived from indigenous knowledge in order to be able to cushion themselves from the impacts of climate change and variability. The significance of the coping strategies varies from region to region, and also from one agro-ecological zone to another. In the Tanzanian case study, various strategies that have been developed by the local communities include traditional terracing (matuta), destocking, tree planting, traditional food preservation methods, drilling traditional wells, construction of locally based water reservoirs (Nkunisa), mixed cropping and crop diversification. The most significant strategies were traditional terracing at $40 \%$ response rates followed by tree planting at $39 \%$ and destocking at $13 \%$ (Table 5). Negative behavioural adjustments were also observed whereby communities no longer enjoy 3 meals per day but have resulted into a single meal per day and/or they eat only one type of food. Other changes include changes in livestock production to zero grazing where fodder is collected from areas around water sources and crop residues and fed to the animals. Also due to poor regeneration some livestock keepers have hugely reduced the size of their cattle (Shemdoe, 2011).

TABLE 5

Coping and adaptation strategies to the impacts of climate variability

\begin{tabular}{lcccc}
\hline & \multicolumn{3}{c}{ Lushoto } & District \\
Mpwapwa District & Frequency & $\begin{array}{c}\text { Response } \\
\%\end{array}$ & Frequency & $\begin{array}{c}\text { Response } \\
\%\end{array}$ \\
\hline Adaptation Measures & & 18 & 80 & 40 \\
Traditional terracing (matuta) & 36 & 8 & 25 & 13 \\
Destocking & 16 & 46 & 78 & 39 \\
Tree Planting & 91 & 1 & 17 & 8 \\
Traditional food storage & 2 & 18 & 0 & 0 \\
methods (vihenge) & & & & \\
Drilling traditional water wells & 37 & & & \\
and construction of & & 7 & 0 & 0 \\
traditional water reservoirs & & 2 & 0 & 0 \\
(Nkunisa) & 13 & $\mathbf{1 0 0}$ & $\mathbf{2 0 0}$ & $\mathbf{1 0 0}$ \\
Crop diversification & 5 & & & \\
Family Planning & $\mathbf{2 0 0}$ & & & \\
TOTAL & & & & \\
\hline
\end{tabular}

Source: Shemdoe, 2011 
In Southwest Nigeria, the most significant indigenous technologies used by the smallholder farming communities in adapting to climate change impacts were: the construction of drainages (28.45\%) and irrigation (21.55\%) (Table 6). The practice of drainage construction was mainly done in swampy areas which were reclaimed for crop production. This involved the use of simple tools such as diggers and shovels to form a large open ditch close to the swamp. The ditch was usually at least one meter below the surface of the land often with a gradient in the normal direction of water flow to allow for drainage. Sometimes, several smaller ditches of about 60-90 $\mathrm{cm}$ deep were made to run between the swamp and the new open ditch. In spite of the benefits arising from this technology, there is also the possibility of upsetting the natural habitat of the area.

Irrigation was commonly practiced though in small scale, mainly in the rainforest zone. This involved the diversion of water streams or pumping water sources such as a well or reservoir in order to supply water to farms. Afforestation was the third most common practice $(2.76 \%)$ and involved planting of trees in areas that have not been forested before or at least in the recent times. Fast growing plant species (usually legumes) were deliberately planted primarily for rapid replenishment of soil fertility. Afforestation is also important in providing fuel wood production, recycling of nutrients, provision of carbon supply to soil micro-organisms, weed suppression, Striga control and improved soil water retention.

It is also noteworthy that a significant number of farmers (18\%) did not adopt any strategy at all. The probable factors that lead to their lack of adoption have been provided in numerous literature and range from lack of financial, technical and institution capacity among others. Farmers also attribute the impacts of climate change to be a consequence for wrong-doing which is punishable by God. As a result they seek divine intervention through prayers and offerings. They also consult with rain makers who are believed to use certain concoctions along with incarnations to induce rain. 
TABLE 6

Strategies/technologies adopted by farmers in coping with climate change impacts

\begin{tabular}{lcccc}
\hline & \multicolumn{4}{c}{ Agro-ecological zones } \\
\hline Strategies/ Technologies & $\begin{array}{c}\text { Swamp } \\
(\mathbf{n = 1 1 9 )}\end{array}$ & $\begin{array}{c}\text { Rainforest } \\
(\mathbf{n = 1 2 0})\end{array}$ & $\begin{array}{c}\text { Savanna } \\
(\mathbf{n = 1 2 3})\end{array}$ & $\begin{array}{c}\text { Overall } \\
(\mathbf{n}=\mathbf{3 6 2})\end{array}$ \\
No adopted strategy & 0.00 & 0.00 & 52.85 & 17.96 \\
Construction of drainages & 86.55 & 0.00 & 0.00 & 28.45 \\
Irrigation & 0.00 & 48.33 & 16.26 & 21.55 \\
Afforestation & 0.00 & 8.33 & 0.00 & 2.76 \\
Channelization of beds & 5.88 & 0.00 & 0.00 & 1.93 \\
FADAMA & 0.00 & 4.17 & 0.00 & 1.38 \\
Planting date adjustment & 3.36 & 0.00 & 4.88 & 2.76 \\
Planting of drought tolerant crops & 1.68 & 0.00 & 0.00 & 0.55 \\
Fertilizer application & 0.00 & 2.50 & 0.00 & 0.83 \\
Use of pesticides & 0.00 & 1.67 & 0.00 & 0.55 \\
Mulching & 0.00 & 2.50 & 0.00 & 0.83 \\
Consulting the rain maker & 0.00 & 0.00 & 1.63 & 0.55 \\
Prayers to God & 1.68 & 0.00 & 0.00 & 0.55 \\
Provision of shelter & 0.00 & 1.67 & 0.00 & 0.55 \\
Others & 0.84 & 7.47 & 0.81 & 3.08 \\
No response & 0.00 & 23.33 & 23.58 & 15.75 \\
\hline
\end{tabular}

Source: Adebayo, Dauda, Rikko, George, et al., 2011

In Sierra Leone, the indigenous technologies and adaptation strategies also varied significantly. Table 7 show that the most significant indigenous climate change adaptation technologies/strategies were; clearing around farm lands $(81 \%)$, manual fencing of farm and setting of rodent traps (80\%), green manure application (66\%), mulching (57\%) and hunting (60.6\%) as the most highly adopted adaptation practices by farmers in Sierra Leone. Irrigation (42.4\%), change of farming dates (41\%) and performance of ancestral ceremony/spiritual invocation $(20.6 \%)$ were also among the numerous practices that were adopted by farmers. However differences in practices were observed within the agro-climatic regions. Farmers in the coastal plains (66\%) and savannah woodlands (84\%) tend to move more from unproductive zones/farmlands for higher yields than their counterparts in Rainforest $(0 \%)$ and Transitional Rainforest/Savanna woodland $(0.8 \%)$. Tree planting $(60 \%)$ was observed more in the savannah woodlands than in Transitional Rainforest/Savanna woodland (5\%). 
TABLE 7

Indigenous technologies and adaptation practices in response to climaterelated problems in Sierra Leone

AGRO-CLIMATIC REGIONS

\begin{tabular}{|c|c|c|c|c|c|}
\hline $\begin{array}{l}\text { Adaptation } \\
\text { practices }\end{array}$ & $\begin{array}{l}\text { Coastal } \\
\text { Plains } \\
\mathrm{N}=125\end{array}$ & $\begin{array}{l}\text { Rainforest } \\
N=125\end{array}$ & $\begin{array}{l}\text { Savanna } \\
\text { Woodlands } \\
\mathrm{N}=125\end{array}$ & $\begin{array}{l}\text { Transitional } \\
\text { Rainforest/ } \\
\text { Savanna } \\
\text { Woodlands }\end{array}$ & TOTAL \\
\hline $\begin{array}{l}\text { Irrigation of farm } \\
\text { land }\end{array}$ & $32(25.6 \%)$ & $46(36.8 \%)$ & $41(32.8 \%)$ & $93(74.4 \%)$ & $139(27.8 \%)$ \\
\hline $\begin{array}{l}\text { Change of crop } \\
\text { varieties }\end{array}$ & $8(6.4 \%)$ & $86(68.8 \%)$ & $99(79.2 \%)$ & $25(20.0 \%)$ & $218(43.6 \%)$ \\
\hline $\begin{array}{l}\text { Fencing of farm } \\
\text { and setting of } \\
\text { rodent traps }\end{array}$ & $59(47.6 \%)$ & $115(92.0 \%)$ & $102(81.6 \%)$ & $124(99.2 \%)$ & $400(80.2 \%)$ \\
\hline Hunting & $44(35.2 \%)$ & $49(39.2 \%)$ & $99(79.2 \%)$ & $111(88.8 \%)$ & $303(60.6 \%)$ \\
\hline Tree planting & $55(44.0 \%)$ & $61(48.8 \%)$ & $75(60.0 \%)$ & $6(4.8 \%)$ & $197(39.4 \%)$ \\
\hline Mulching & $75(60.0 \%)$ & $33(26.4 \%)$ & $92(73.6 \%)$ & $85(68.0 \%)$ & $285(57.0 \%)$ \\
\hline $\begin{array}{l}\text { Clearing around } \\
\text { farm }\end{array}$ & $91(72.8 \%)$ & $111(88.8 \%)$ & $119(85.2 \%)$ & $86(68.8 \%)$ & $407(81.4 \%)$ \\
\hline $\begin{array}{l}\text { Performance of } \\
\text { ancestral } \\
\text { ceremony/spiritual } \\
\text { invocation }\end{array}$ & $2(1.6 \%)$ & $0(0.0 \%)$ & $13(10.4 \%)$ & $88(70.4 \%)$ & $103(20.6 \%)$ \\
\hline $\begin{array}{l}\text { Green manure } \\
\text { application }\end{array}$ & $92(73.6 \%)$ & $9(7.2 \%)$ & 113(90.4\%) & $118(94.4 \%)$ & $332(66.4 \%)$ \\
\hline $\begin{array}{l}\text { Use of indigenous } \\
\text { weather forecasts }\end{array}$ & $51(40.8 \%)$ & $25(20.0 \%)$ & $28(22.4 \%)$ & $49(39.2 \%)$ & $153(30.6 \%)$ \\
\hline $\begin{array}{l}\text { Use of scientific } \\
\text { weather forecasts }\end{array}$ & $1(0.8 \%)$ & $2(1.6 \%)$ & $4(3.2 \%)$ & $2(1.6 \%)$ & $9(1.8 \%)$ \\
\hline $\begin{array}{l}\text { Change of } \\
\text { farming dates }\end{array}$ & $37(29.6 \%)$ & $36(28.8 \%)$ & $115(92.0 \%)$ & $17(13.6 \%)$ & $205(41.0 \%)$ \\
\hline $\begin{array}{l}\text { Move from } \\
\text { climate } \\
\text { risk/unproductive } \\
\text { farm land }\end{array}$ & $82(65.6 \%)$ & $0(0.0 \%)$ & $105(84.0 \%)$ & $1(0.8 \%)$ & $188(37.6 \%)$ \\
\hline
\end{tabular}

Source: Morlai, Mansaray and Vandy, 2011

Farmers in Sierra Leone have also resulted in changing their crop varieties in order to cope with the changing climate. In the coastal plains there was high adoption of new agricultural crops such as rice, sweet potatoes, cassava, pepper and maize as old crops such as carrots and lettuce were gradually disappearing. In the savanna woodlands only small amounts of lettuce, carrots and cabbages 
were being produced. In the Transitional zone, cowpea, oil palm, rubber, sisal, and sugar cane productions were also gradually disappearing; while yams, avocado and citrus plants were gradually disappearing or grown at a low quantity in the rainforest zone. Generally, adoption of modern innovative applications was rarely observed across the agro-climatic regions. For instance the use of scientific weather forecasts recorded only an average of about $1.8 \%$ of all the respondents.

Another example of an innovative indigenous technology was in the area of pest control (especially in the eradication of grasshoppers). In this case, the grasshoppers were crushed and mixed with water. The solution, which produces a stinky odour was then used to spray on to the plants to eradicate the grasshoppers. Also practiced is the spraying of plants with a mixture of cigarette filters and water (which has been left in the sun for a certain period) to eradicate grasshoppers and other insects that attack plants. Farmers also complemented their adaptation strategies with indigenous meteorological predictions. In Sierra Leone, it was observed that smallholder farmers, particularly those in the rainforest zone $(100 \%)$ and transitional zone (51\%) have been using indigenous weather predictions to determine the time to commence farming operations. In many instances however, the farmers were concerned that these predictions were continuously failing them unlike before. Table 8 provides some of the indigenous observations made by farmers in the coastal plains of Sierra Leone in predicting the weather and their effectiveness in the recent times. 
TABLE 8

Description of indigenous meteorological predictions in the coastal plains Description of predictions How well it has worked

Lunar Direction: Leaning of the new moon in a Not for the last four years westward direction signifies heavy rainfall in that particular month. Towards the east, hot dry season would be expected.

Appearance of a flower called "Lortor" in Loko

Not for the last four years language indicates the beginning of raining season Croaking of frogs indicates the beginning of raining season

Appearance of a large number of termites at the beginning of raining season indicates excess rainfall and long raining season.

Crying sound of a particular insect called "Tengai" in Loko indicates the beginning of dry season.

Dividing cloud with blue coloured sky in between signifies very hot dry season

Three particular stars appearing in a straight line at 19:00 GMT indicates hot dry season.

Sea appearing black at a distance with dark cloud signifies rains.

Clear sea and excess wind indicates hot sunny day and dry season.

Germination of yams in March indicates that rainy season is drawing near.

Appearance of certain types of snakes signifies raining season.

Appearance of mushrooms and millipedes indicates rainy season.

Appearance of cattle egrets indicates that raining Still works well season is drawing near.

Source: Morlai, Mansaray and Vandy 2011

\section{Conclusions and Recommendations}

The study sought to establish the evidence of climate change variability and impacts and to document the specific indigenous technologies employed by several smallholder farming communities in selected case study countries in Nigeria, Tanzania, and Sierra Leone. The major findings from the study showed that there was great awareness of climate change among the communities studied with most farmers stating that they have been experiencing climate variability and change which have intensified in the recent times. As a result and as a coping 
strategy, they have applied several indigenous technologies to avert the crisis and cope with the changes. The most popular ones being traditional terracing, tree planting, construction of drainages, irrigation, use of local herbicides and prayers to God. However, it remains unclear on the effectiveness of those indigenous technologies in light of further climate changes.

Based on the key findings from the research study, it is recommended that some of the innovative indigenous adaptation technologies identified in this study be out scaled and up scaled in other parts of African farming communities where similar climate change impacts are observed. However, it will be important to further examine the efficacy and effectiveness of those indigenous technologies prior to application to other areas. This could be achieved through innovation incubation schemes to test the workability of the technologies in the destination areas. Again, more models should be developed by researchers to track climate variability and change and its impacts on the economy, agriculture, health and community livelihoods among others. This will ensure that enough data is available to simulate more accurately the trends in climate change and variability in the continent and especially in sub Saharan Africa. Finally, there is need for all stakeholders including researchers, policymakers, civil society groups, private sector actors, farmers and farmers' associations to work together in designing effective climate change adaptation and mitigation strategies in an innovation systems approach. Such efforts should also focus on increasing adaptive capacity of stakeholders to not only the short term climate variability but more importantly for the long term climate change impacts.

\section{Acknowledgement}

This paper was produced as part of the implementation of the African Technology Policy Studies Network (ATPS) Phase VI Strategic Plan, 2008-2012 funded by ATPS donors including the Ministerie van Buitenlandse Zaken (DGIS) the Netherlands and the Rockefeller Foundation, amongst others. The authors hereby thank the research coordinators represented by their principal investigators namely, Adebayo, et al. (Nigeria), Enete, et al. (Nigeria), Morlai, et al. (Sierra Leone) and Shemdoe, (Tanzania) for their efforts in the research process. 


\section{References}

Adebayo, K., Dauda, T.O., Rikko, L.S., George, F.O.A., Fashola, O.S., Atungwu, J.J., Iposu, S.O., Shobowale, A.O., and Osuntade, O.B. (2011). Emerging and Indigenous Technology for Climate Change Adaptation in Southwest Nigeria. Research Paper, African Technology Policy Studies Network (ATPS), Nairobi, Kenya.

Anim, F.D.K. (1999). A Note on the Adoption of Soil Conservation Measures in the Northern Province of South Africa. Journal of Agricultural Economics, Vol.50, pp. 336-345.

Anley, Y., Bogale, A., and Haile-Gabriel, A. (2007). Adoption Decision and Use Intensity of Soil and Water Conservation Measures by Smallholder Subsistence Farmers in Dedo District, Western Ethiopia. Land Degradation and Development, Vol. 18, pp. 289-302.

Araya, B. and Adjaye, J.A. (2001). Adoption for Farm Level Soil Conservation Practices in Eritrea. Indian Journal of Agricultural Economics, Vol. 56, pp. 239-252.

Enete, A., Ignatius, I.M., Josephat, C.M., Anthony, N.O., Elizabeth, A.O and Fidelis, E. (2011). Indigenous Agricultural Adaptation to Climate Change: Study of Southeast Nigeria. Research Paper, African Technology Policy Studies Network (ATPS) Nairobi, Kenya.

Food and Agriculture Organization (FAO) (2007). Adaptation to Climate Change in Agriculture, Forestry and Fisheries: Perspectives, Framework and Priorities. FAO, Rome.

Intergovernmental Panel on Climate Change (IPCC) (2007). The Physical Science Basis. Contribution of Working Group I to the Fourth Assessment Report of the Intergovernmental Panel on Climate Change. In S. Solomon, D. Qin, M. Manning, Z. Chen, M. Marquis, K.B. Averyt, M. Tignor and H.L. Miller (Eds.).Cambridge University Press, Cambridge, United Kingdom and New York, NY, USA, 996 pp.

Maddison, D. (2006). The Perception of and Adaptation to Climate Change in Africa. CEEPA Discussion paper No. 10, University of Pretoria, South Africa.

Morlai, T.A., Mansaray, K., and Vandy, G. (2011) Enhancing agricultural yields by smallholder farmers through integrated climate change adaptation programme in Sierra Leone. Research Paper, African Technology Policy Studies Network (ATPS), Nairobi, Kenya. 
Ozor, N., Madukwe, M.C., Onokala, P.C., Enete, A., Garforth, C.J., Eboh, E., Ujah, O. and Amaechina E.E. (2010). A Framework for Agricultural Adaptation to Climate Change in Southern Nigeria. A Development Partnerships in Higher Education (DelPHE) 326 Project Executive Summary supported by DFID and the British Council.

Shemdoe, R.S. (2011). Tracking Effective Indigenous Adaptation Strategies on Impacts of Climate Variability on Food Security and Health of Subsistence Farmers in Tanzania. Research Paper, African Technology Policy Studies Network (ATPS). Nairobi, Kenya.

Watson, D. (2010). Climate Change, Cropping Systems and Coping Strategies. Impacts of Climate Change on Food Security in sub-Saharan Africa. Proceedings of the 14th Annual Symposium of the International Association of Research Scholars and Fellows, IITA. 